\title{
Effectiveness of Conceptual Change Text in Reducing Acid-Base Misconceptions
}

\author{
Rosyidah Syafaatur Rohmah ${ }^{1^{*}}$ and Irma Ayu Virtayanti \\ ${ }^{1}$ Department of Chemistry Education, Faculty of Teacher Training and Education, \\ Universitas Billlfath, Lamongan, Indonesia \\ *E-mail: rosyrohmah@gmail.com
}

Received: 08 March 2021; Accepted: 15 April 2021; Published: 30 June 2021

\begin{abstract}
Students had difficulty understanding the acid-base concept because of its complex nature. This difficulty could lead to an acid-base misconception. One of the learning tools that can be used to overcome misconceptions was Conceptual Change Text. This study aimed to determine the effectiveness of the Conceptual Change Text in reducing acid-base misconceptions. This study used one group pre-test post-test design with 18 Basic Chemistry II students at Billfath University. An acid-based diagnostic test determined students' misconceptions. The results showed there are nine and one misconceptions in pre-test and posttest, respectively. The application of the Conceptual Change Text was successful in reducing acid-base misconceptions with an effectiveness percentage of $97.76 \%$.
\end{abstract}

Keywords: acid-base, conceptual change text, misconception

DOI : https://doi.org/10.15575/jtk.v6i1.9870

\section{Introduction}

Acid-base is an important basic concept in chemistry and is related to everyday life (Ultay $\&$ Calik, 2016). The acid-base concept was first taught to junior high school students, then in grade eleventh senior high school, and then continued in the college of natural science major and chemistry major in Basic Chemistry II and Inorganic-Physic Chemistry subject. Acid-base consists of several concepts, including acid base theory, strength, reaction, and $\mathrm{pH}$. Acid-base is related to other chemistry concepts, such as buffer solution, hydrolysis, chemical equilibrium, chemical reaction, stoichiometry, and solution (Amry et al., 2017; Artdej et al., 2010; Sesen \& Tarhan, 2011).

Previous research has shown that students had difficulty understanding the concept of acidbase (Demirciouglu, 2009; Cooper et al., 2016; Sadhu et al., 2017; Muchtar \& Harizal, 2012).
Based on an interview with a lecturer in Basic Chemistry II, it was found that students of the Chemistry Education Department at Billfath University had difficulty understanding the concept of acid-base. Student difficulties can lead to acid-base misconceptions. The results of previous studies reported that there was the misconception of acid-base at all levels from junior high school (Sevim \& Tarim, 2017), high school (Demirciouglu, 2009; Sadhu et al., 2017; Muchtar \& Harizal, 2012; Lathifa, 2018), even up to college (Ultay \& Calik, 2016; Cooper et al., 2016).

The acid-base misconceptions experienced by students must be corrected to obtain a complete and correct understanding. According to constructivist theory, students construct their understanding. To correct misconceptions, students must experience conceptual change. One of the concept change learning tools is Conceptual Change Text (CCT). Acid-base misconceptions can be 
corrected by CCT (Demircioulgu, 2009; Sevim \& Tarim, 2017; Utami et al., 2017).

The results of previous studies stated that CCT was effective in reducing electrochemical misconceptions (Onder, 2017; Yuruk, 2007), matter and its changes (Beerenwinkel et al., 2011; Durmus \& Bayraktar, 2010; Rohmah, 2017; Rohmah et al., 2020), heat and temperature (Yuruk \& Eroglu, 2016; Turgut \& Gurbuz, 2012), solutions (Pinarbasi et al., 2006; Ultay et al., 2015), acid-base (Demirciouglu, 2009; Sevim \& Tarim, 2017; Utami et al., 2017). CCT is a learning tool developed from the theory of concept change and is suitable for remediating misconceptions. Concept change is the replacement of misconceptions with correct concepts. Posner proposes four conditions so that concept change can occur: students must feel dissatisfaction with the concepts they have, true concepts must be intelligible, plausible, and fruitful (Cepni \& Cil, 2010). CCT fulfilled the four requirements so that CCT was chosen as a treatment instrument.

CCT is a reading that is specifically designed to find out student misconceptions in explaining concepts or solving problems about related topics and correcting misconceptions that occur (Muntholib et al., 2018). Previous research (Demirciouglu, 2009; Sevim \& Tarim, 2017; Utami et al., 2017) showed that CCT could reduce misconceptions in junior and senior high school students, but it has not been studied in college students. The novelty of this research is the use of CCT to reduce college student misconceptions.

Based on the description above, a study was conducted with the title "Effectiveness of Conceptual Change Text in Reducing AcidBase Misconceptions". The research objectives were to determine: (1) acid-base misconceptions experienced by the Billfath University Chemistry Education Study Program students; (2) the effectiveness of Conceptual Change Text to reduce acid-base misconceptions.

\section{Research Method}

The research design used was a descriptive and pre-experimental one group pre-testpost-test design. Descriptive research is used to describe student misconceptions, while one group pre-test-post-test design is needed to determine the effectiveness of CCT in reducing acid-base misconceptions.

The statistical analysis used in the study was paired sample t-test and the percentage of misconceptions reduction. Paired sample ttest was used to determine the effectiveness of CCT in correcting acid-base misconceptions. The t-test analysis technique was calculated using the SPSS 16 for the windows program. CCT is categorized as effective in correcting misconceptions if there is a significant difference between the pre-test and post-test scores. The criterion for rejection of $\mathrm{H}_{0}$ is if $\mathrm{t}_{\text {count }}>\mathrm{t}_{\text {table }}$ or a significance value $<$ 0.05 . If $t_{\text {count }} \leq t_{\text {table, }}$ then $\mathrm{H}_{0}$ is accepted or a significance value $>0.05$. The reduction percentage of misconceptions is formulated as Eq. (1).

$$
E=\frac{\text { Pretest percentage-Postest percentage }}{\text { Pretest pecentage }} \times 100 \% \text { (1) }
$$

CCT is considered effective if the $E$ value is $\geq$ 31\% (Hake, 1998). The interpretation of the level of effectiveness follows the criteria in Table 1.

Table 1. Criteria for Effectiveness of CCT from

\begin{tabular}{cc}
\multicolumn{2}{c}{ Misconception Data (Hake, 1998) } \\
\hline$E$ & Criteria \\
\hline$E \geq 70$ & Effectiveness level of using CCT is \\
high \\
$30 \leq E<$ & $\begin{array}{c}\text { Effectiveness level of using CCT is } \\
\text { moderate }\end{array}$ \\
$\begin{array}{c}E<30 \\
\text { Effectiveness level of using CCT is } \\
\text { low }\end{array}$ \\
\hline
\end{tabular}

The research was conducted on 15 May - 23 July 2020 at Billfath University. The research subjects were 18 students of the Chemistry Education study program, Billfath University, who are currently taking and have been taking Basic Chemistry II courses. 
The research instrument used was measurement and treatment instruments. The measurement instrument is the acid-base diagnostic test and the treatment instrument is the acid-base CCT. The measurement instrument was an acid-base diagnostic test in the form of 20 multiple choice questions with answer reasons adapted from previous studies (Lathifa, 2018; Muntholib et al., 2018).

The research instrument, the acid-base diagnostic test, was then tested on 36-second semester students of the Chemistry Education study program, Lambung Mangkurat University. From the trial results, the reliability of the acid-base diagnostic test was obtained at 0.708 , which is considered a high criterion (Landis \& Koch, 1977). Therefore, the research instrument is valid and reliable, so it can be used to collect research data.

The treatment instrument was in the form of an acid-base CCT. Two validators validated the research instrument. The results of the content validity of the acid-base diagnostic test were 97.5\% which was considered very high (Landis \& Koch, 1977), and the content validity of the acid-base CCT was $97.82 \%$ with very feasible criteria (Landis \& Koch, 1977).

The acid-base CCT developed in this study was adapted from Cepni and Cil (2010). The acidbase CCT consists of five parts. In part I, students are given information about acidbase found in everyday life. Then, students must answer questions related to acid-base theory, strength, $\mathrm{pH}$, and reactions. Students' answers show their misconceptions. In part II, 20 statements are given, students put a checkmark on the statements that are considered true. The statement in part II is a common misconception of acid-base. So, part II shows the misconceptions experienced by students. In parts I and II, students experience dissatisfaction with their wrong concept. Part III contains statements that are true concepts. Part III shows that the correct concept is easier to understand (intelligible). In part IV, students are given a reading to find the correct concept. Part IV affirms that the concept of truth is more plausible. In part $\mathrm{V}$, students answer questions to determine the mastery of the acid-base concept. The student's answer shows the new concept they have. Part $\mathrm{V}$ proves that the true concept is more fruitful.

The research was conducted online with the WhatsApp Group (WAG) due to the Covid-19 pandemic. Acid-base learning uses online learning. Online learning is learning where most or all of the material is presented online to have no face-to-face class (Sari et al., 2020). WAG was chosen because it does not need to install additional applications, is easy to use, can still run even though the internet network is less stable, it can add files such as documents, videos, audio (Sari et al., 2020).

In this research, students joined the Acid-Base Research WAG. The research lasted for four meetings. In the first meeting, students worked on the acid-base pre-test via Google form. The pre-test aims to find out the misconceptions of acid-base that students have. Students were given acid-base CCT as a learning tool to reduce misconceptions at the second and third meetings. Next, students work on their acid-base CCT by directly editing the acid-base CCT files distributed in Word. Finally, students worked on acid-base posttest questions via Google form to determine the acid-base misconceptions that students still had in the fourth meeting.

The pre-test and post-test values were analyzed by using the paired sample t-test to determine the effectiveness of the CCT. The acid-base misconception was obtained from the consistency of students' wrong answer choices. The percentage reduction in misconceptions during the pre-test and posttest was calculated to determine the effectiveness of the CCT in reducing misconceptions.

\section{Result and Discussion}

From the pre-test results, it was found that students experienced nine acid-base misconceptions. Most of the students assumed that all acid-base reactions always produced salt (27.8\%). Complete data are given in Table 3. 
The effectiveness of acid-base CCT was seen from the paired sample t-test and the reduction percentage of misconception. The results of the paired sample t-test are shown in Table 2.

From the two-way t-test, the results of $\mathrm{H}_{0}$ are rejected because of the probability of rejection error $\mathrm{H}_{0}<\alpha(0.05)$ so that it can be concluded that there is a significant difference between the pre-test and post-test scores after being given improvements with acid-base CCT with a confidence level of $95 \%$.

Table 2. Paired Sample t-Test Results

\begin{tabular}{llllllllll}
\hline & Mean & $\begin{array}{c}\text { Std. } \\
\text { Deviation }\end{array}$ & $\begin{array}{c}\text { Std. Error } \\
\text { Mean }\end{array}$ & $\begin{array}{c}\text { 95\% Confidence Interval } \\
\text { of the Difference }\end{array}$ & T & df & $\begin{array}{c}\text { Sig. (2- } \\
\text { tailed) }\end{array}$ \\
\hline Pair 1 & $\begin{array}{l}\text { Pre-test } \\
\text { Post- } \\
\text { test }\end{array}$ & $-3.38889 \mathrm{E} 1$ & 18.19466 & 4.28852 & -42.93688 & -24.84090 & -7.902 & 17 & .000 \\
\hline
\end{tabular}

The effectiveness of acid-base CCT was obtained from the percentage reduction of misconceptions of $97.76 \%$, with the high category shown in Table 3. There are four acidbase concepts studied: acid-base theory, acidbase strength, $\mathrm{pH}$, and acid-base reactions. From the pre-test results obtained nine acidbase misconceptions, while in the post-test, only one acid-base misconception was found. This means that the acid-base CCT is effective in reducing acid-base misconceptions. This finding is consistent with previous studies (Demirciouglu, 2009; Sevim \& Tarim, 2017; Utami et al., 2017) regarding the effectiveness of CCT in reducing acid-base misconceptions.

Table 3. Acid-Base Misconceptions

\begin{tabular}{|c|c|c|c|c|}
\hline No & Misconceptions & $\begin{array}{l}\text { Pre- } \\
\text { test } \\
\text { (\%) }\end{array}$ & $\begin{array}{c}\text { Post- } \\
\text { test } \\
(\%)\end{array}$ & $\begin{array}{l}\text { Effectiveness } \\
\text { (E) }\end{array}$ \\
\hline 1. & Lewis acids are compunds that release $\mathrm{H}^{+}$ions in water & 5.6 & 0 & 100 \\
\hline 2. & Lewis bases are bases that produce $\mathrm{OH}^{-}$ions in water & 5.6 & 0 & 100 \\
\hline 3. & Acid base strength is determined by the concentration of solution & 11.1 & 0 & 100 \\
\hline 4. & The strength of a base is determinded by the $\mathrm{pH}$ value & 11.1 & 0 & 100 \\
\hline 5. & $\begin{array}{l}\text { At the same concentration, the } \mathrm{pH} \text { of a strong acid with a valence } \\
\text { of } 1=\mathrm{pH} \text { of a strong acid with a valence of } 2\end{array}$ & 5.6 & 0 & 100 \\
\hline 6. & The $\mathrm{pH}$ value cannot be smaller than 0 & 11.1 & 0 & 100 \\
\hline 7. & $\begin{array}{l}\text { The } \mathrm{pH} \text { of a strong acid cannot be determined if the concentration } \\
\text { is too concentrated }\end{array}$ & 11.1 & 0 & 100 \\
\hline 8. & $\begin{array}{l}\text { The addition of a strong acid to a strong base will increase the } \\
\text { basicity }\end{array}$ & 5.6 & 0 & 100 \\
\hline 9. & All acid-base reactions always produce salt & 27.8 & 5.6 & 79.86 \\
\hline & Average & 10.51 & 0.62 & 97.76 \\
\hline
\end{tabular}

$5.6 \%$ of students thought that Lewis acid is a compound that releases $\mathrm{H}^{+}$ions in water. This misconception was caused by students not distinguishing the definition of acid by Arrhenius and Lewis. This can be seen from the reasons for the answers of students who think that $\mathrm{BF}_{3}$ is a Lewis acid because it can release
$\mathrm{H}^{+}$ions in water. This is consistent with research conducted by Lathifa (2018).

Students assume that the acid-base strength is determined by the solution concentration (11.1\%) and $\mathrm{pH}$ (11.1\%). This misconception can be seen from the reasons for the answers of students who wrote that the greater the 
acid concentration, the greater the strength of the acid, the factors that determine the acid strength of a substance are the concentration and the number of $\mathrm{H}^{+}$ions in the solution, the higher the $\mathrm{pH}$ value, the stronger the base will be. Students tend only to memorize examples of strong acids and weak acids without understanding that the strength of the acidbase is determined by the degree of ionization. This is similar to the results of previous studies (Lathifa, 2018; Muntholib et al., 2018).

$27.8 \%$ of students think that all acid-base reactions produce salt. This is because students only know examples of Arrhenius acid-base reactions that produce salt. Students do not understand that Lewis acidbase reactions do not produce salts. This is the same as previous studies (Ultay \& Calik, 2016; Muntholib et al., 2018).

CCT was proven to effectively reduce acidbase misconceptions, which was proven by reducing misconceptions experienced by students. This follows the results of previous studies (Demirciouglu, 2009; Sevim \& Tarim, 2017; Utami et al., 2017), which state that CCT effectively reduces acid-base misconceptions in junior high and high school students. Furthermore, in students, acid-base misconceptions were reduced, from nine misconceptions at pre-test to only one misconception left at post-test, as shown in Figure 1. This shows that CCT is also effective in reducing acid-base misconceptions in college students.

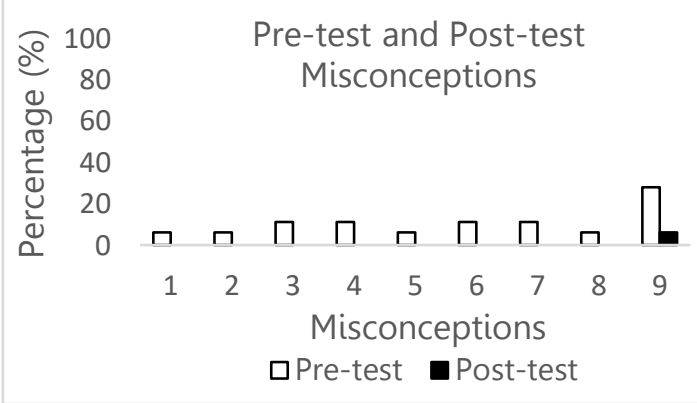

Figure 1. Graph of Pre-test and Post-test Misconceptions

\section{Conclusion}

From the results and discussion, it was found that there were nine acid-base misconceptions. However, CCT effectively reduces acid-base misconceptions, as evidenced by the t-test results showing a significant difference between the pre-test and post-test scores after being given CCT. The effectiveness percentage is $97.76 \%$, and only one misconception is found left at posttest.

\section{References}

Amry, U. W., Rahayu, S., \& Yahmin. (2017). Analisis miskonsepsi asam basa pada pembelajaran konvensional dan Dual Situated Learning Model (DSLM). Jurnal Pendidikan: Teori, Penelitian, dan Pengembangan, 2(3), 385-391. Retrieved from http://journal.um.ac.id/index.php/jptpp/ article/view/8636

Artdej, R., Ratanaroutai, T., Coll, R. K., \& Thongpanchang, T. (2010). Thai Grade 11 students' alternative conceptions for acid-base chemistry. Research in Science \& Technological Education, 28(2), 167183.

http://dx.doi.org/10.1080/02635141003 748382

Beerenwinkel, A., Parchmann, I., \& Grasel, C. (2011). Conceptual change texts in chemistry teaching: A study on the particle model of matter. International Journal of Science and Mathematics Education, 9(1), 1235-1259. https://doi.org/10.1007/s10763-0109257-9

Cepni, S., \& Cil, E. (2010). Using a conceptual change text as a tool to teach the nature of science in an explicit reflective approach. Asia-Pacific Forum on Science Learning and Teaching, 11(1), 1-29. Retrieved from https://www.eduhk.hk/apfslt/v11_issue1 /cepni/cepni7.htm 
Cooper, M. M., Kouyoumdjian, H., \& Underwood, S. M. (2016). Investigating students' reasoning about acid-base reactions. Journal of Chemical Education, 93(1), 1703-1712. https://doi.org/10.1021/acs.jchemed.6b 00417

Demircioglu, G. (2009). Comparison of the effects of conceptual change texts implemented after and before instruction on secondary school students' understanding of acid-base concept. Asia-Pacific Forum on Science Learning and Teaching, 10(2), 1-29. Retrieved from https://www.eduhk.hk/apfslt/v10_issue2 /gokhan/index.htm

Durmus, J., \& Bayraktar, S. (2010). Effects of conceptual change texts and laboratory on fourth grade students' understanding of matter and change concepts. Journal of Science Education and Technology, 19(1), 498-504. https://doi.org/10.1007/s10956-0109216-9

Hake. (1998). Interactive-engagement versus traditional methods: A six-thousandstudent survey of mechanics test data for introductory physics courses. American Journal Physic, 66(1), 64-74. https://doi.org/10.1119/1.18809

Landis, J. R., \& Koch, G. G. (1977). The measurement of observer agreement for categorical data. Biometrics, 33(1), 159174. https://doi.org/10.2307/2529310

Lathifa, U. (2018). Correcting students' misconception in acid and base concept using PDEODE instruction strategy. Unnes Science Education Journal, 7(2), 170-177. https://doi.org/10.15294/usej.v7i2.2320 2

Muchtar, Z., \& Harizal. (2012). Analyzing of students' misconceptions on acid-base chemistry at senior high schools in medan. Journal of Education and
Practice, 3(15), 65-74. http://digilib.unimed.ac.id/id/eprint/398

Muntholib, Mayangsari, J., Pratiwi, Y. N., Muchson, Joharmawan, R., Yahmin, \& Rahayu, S. (2018). Development of simple multiple-choice diagnostic test of acid-base concepts to identify students' alternative conceptions. Proceeding of Advances in Social Science, Education and Humanities, 251268. Malang: First International Conference on Science, Mathematics, and Education. https://dx.doi.org/10.2991/icomse17.2018 .45

Onder, I. (2017). The effect of conceptual change texts supplemented instruction on students' achievement in electrochemistry. International Online Journal of Educational Sciences, 9(4), 969-975. Retrieved from https://iojes.net/index.jsp?mod= makale _ing_ozet\&makale_id=40666

Pinarbasi. T., Canpolat, N., Bayrakceken, S., \& Geban, O. (2006). An investigation of effectiveness of conceptual change textoriented instruction on students' understanding of solution concepts. Research in Science Education, 36(1), 313-335. https://doi.org/10.1007/s11165-0059003-4

Rohmah, R. S. (2017). Pengaruh teks perubahan konsep terhadap perbaikan kesalahan konsep materi dan perubahannya [Unpublished master's thesis]. Universitas Negeri Malang. Retrieved from http://repository.um.ac.id/id/eprint/601 68

Rohmah, R. S., Fariati, \& Ibnu, S. (2020). Effect of conceptual change texts on physical inorganic chemistry students' misconceptions of matter and its changes. AIP Conference Proceedings, 2215 020020. https://doi.org/10.1063/5.0000492 
Sadhu, S., Timaz, M. T., Cahyani, V. P., Laka, A. P., Annisa, D., \& Fahriyah, A. R. (2017). Analysis of acid-base misconceptions using modified certainty of response index (CRI) and diagnostic interview for different student levels cognitive. International Journal of Science and Applied Science: Conference Series, 1(2), 91-100.

https://doi.org/10.20961/ijsascs.v1i2.51 26

Sari, I., Sinaga, P., Hernani, \& Solfarina. (2020). Chemistry learning via distance learning during the Covid-19 pandemic. Tadris: Jurnal Keguruan dan Ilmu Tarbiyah, 5(1), 155-165. https://doi.org/10.24042/tadris.v5i1.634 6

Sesen, B. A., \& Tarhan, L. (2011). Activelearning versus teacher-centered instruction for learning acid and base. Research in Science \& Technological Education, 29(2), 295-226. https://doi.org/10.1080/02635143.2011. 581630

Sevim, S., \& Tarim, S. S. (2017). Comparison of the conceptual change of analogies and conceptual change texts in eliminating students' alternative conceptions for acids and bases. Turkish Journal of Teacher Education, 6(1), 47-60. Retrieved from http://tujted.com/makale/637

Turgut, U., \& Gurbuz, F. (2012). Effect of conceptual change text approach on removal of students' misconceptions about heat and temperature. International Journal Innovation and Learning, 11(4), 386-403.
http://dx.doi.org/10.1504/IJIL.2012.0471 39

Ultay, N \& Calik, M. (2016). A comparison of different teaching designs of 'acids and bases' subject. Eurasia Journal of Mathematics, Science \& Technology Education, 12(1), 57-86. https://doi.org/10.12973/eurasia.2016.1 $422 \mathrm{a}$

Ultay, N., Durukan, U. G., \& Ultay, E. (2015). Evaluation of the effectiveness of conceptual change texts in the REACT strategy. Chemistry Education Research and Practice, 16, 22-38. https://doi.org/10.1039/C4RP00182F

Utami, D. B., Rahmawati, Y., \& Slamet, R. (2017). Penggunaan conceptual change text dengan model pembelajaran $5 \mathrm{E}$ untuk mengatasi miskonsepsi siswa pada materi asam basa di SMAN 4 Tambun Selatan. Jurnal Riset Pendidikan Kimia, $7(1), \quad 30-37$. https://doi.org/10.21009/JRPK.071.10

Yuruk, N. (2007). The effect of supplementing instruction with conceptual change texts on students' conception of electrochemical cells. Journal of Science Education and Technology, 16(6), 515523. http://dx.doi.org/10.1007/s10956007-9076-0

Yuruk, N., \& Eroglu, P. (2016). The effect of conceptual change texts enriched with metaconceptual processes on preservice science teachers' conceptual understanding of heat and temperature. Journal of Baltic Science Education, 15(6), 693-705. Retrieved from http://oaji.net/articles/2016/9871482502823.pdf 